\title{
Recreation carrying capacity estimations to support beach management at Praia de Faro, Portugal
}

\author{
Daniel A. Zacarias ${ }^{\mathrm{a}, *}$, Allan T. Williams ${ }^{\mathrm{b}}$, Alice Newton ${ }^{\mathrm{c}}$ \\ ${ }^{a}$ Universidade Eduardo Mondlane, Escola Superior de Hotelaria e Turismo de Inhambane. Av. Samora Machel, Inhambane C.P 75. Mozambique \\ ${ }^{\mathrm{b}}$ Swansea Metropolitan University, University of Wales, School of Natural E' Built Environment, Faculty of Applied Design E' Engineering, Mt. Pleasant, Swansea, Wales, UK \\ ${ }^{\mathrm{c}}$ Universidade do Algarve, Faculdade de Ciências e Tecnologia, Departamento de Química e Bioquímica, Portugal
}

Keywords:

Recreation

Beach management

Carrying capacity

Praia de Faro

\begin{abstract}
A B S T R A C T
The purpose of this research paper is to outline the theory and practice of tourism carrying capacity assessment and its relevance as a management tool for coastal management. Based on the Tourism Carrying Capacity Assessment for Protected Areas Framework and the Image Capture Technique associated with the PAOT (people at one time) approach, this paper explores Praia de Faro as the study area and attempts to assess the optimum number of people that should be allowed without jeopardizing the surrounding ecological, social and cultural environments. Results showed that the physico-ecological carrying capacity should be between 1385 and 2628 visitors/day with maximum impact acceptability curves being 305 and 608 tourists (for local people and tourists respectively). Although there was a significant difference between the physico-ecological and socio-cultural carrying capacity, this study suggests that the physico-ecological carrying may be applied for ecosystem management, whilst the socio-cultural carrying capacity may be addressed when management objectives are tourists and beach users.
\end{abstract}

(c) 2011 Elsevier Ltd. All rights reserved.

\section{Introduction}

Beaches are defined as "the zone of unconsolidated material that extends landward from the low water line to the place where there is a marked change in material or physiographic form, or to the line of permanent vegetation ... having the mean low water line as the seaward limit" (Shore Protection Manual 1984:10) and are increasingly a great source of income for many countries due to the overall tourism growth that directs people to the seashore to enjoy nature, escape crowds and for relaxation (Vaz, Williams, Pereira da Silva, \& Phillips, 2009).

Examples of this significance can be found globally. In Spain, a mere $0.001 \%$ of the beach generated more than $10 \%$ of the Gross Domestic Product (GDP) (Piqueras, 2005); at Miami beach, tourism is worth US\$2.4 billion annually in foreign exchange and in Florida it is worth US\$65 billion to the state's economy (Houston, 2002); in Barbados beach tourism worth > US\$13 million to the local economy (Dharmaratne \& Braithwaite, 1998). These values outline that beach conservation and appropriate management should be a priority action, especially considering that around $40 \%$ of the

\footnotetext{
* Corresponding author.

E-mail address: danieldream15@yahoo.com.br (D.A. Zacarias).
}

human population live on or near the coast where coastal tourism increases pressure on the physical, socio-economic and cultural environments of host communities. As such, the values outline that conservation and management are rather important in these areas as a way to mitigate the negative impacts driven by tourism.

The challenge is how to integrate the needs of all coastal zone stakeholders in a sustainable planning process that considers environmental, socio-economic and cultural dimensions (Kanji, 2006)? As the beauty and environmental quality of tourist destinations are seemingly what attracts tourists, and local people are increasingly anxious to participate in and draw the benefits of tourism, while preserving their own identities, the natural environment, and the historic and cultural heritage from the impact of uncontrolled tourism (Manning, 1998). Management of coastal tourism has become not only a matter of managing common and sensitive resources, but also meeting community goals, perceptions and attitudes in order to provide long-term sustainability of not only the activity, but also the preservation (a hard approach to conservation) of the coastal area.

Despite the severe limitations associated with the carrying capacity concept, it remains "a useful concept for environmental management, especially in providing insights about the interaction of human activities with the environment" (Papageorgiou \& Brotherton, 1999:272). Defined as the "maximum number of people that may 
visit a tourism destination at the same time, without causing destruction of the physical, economic and socio-cultural environment and an unacceptable decrease in the quality of the visitor' satisfaction" (WTO, 1981), carrying capacity has been described as an appropriate tool for beach management, as it "enables the preservation of the high quality and quantity of coastal resources whilst meeting not only the current needs, but also securing long-term economic and ecological benefits for future generations" (UNEP/PAP, 1997:8).

Pereira da Silva (2002a, b) suggests that development objectives are determinant in the calculation of carrying capacity and can help manage the inevitable negative impacts from leisure activities; whilst Munar (2002) outlined that the carrying capacity provides the optimum level upon which resources can deteriorate or damage to the ecosystems are irreversible, providing a mathematical formula of how many tourists are enough. Mexa and Coccossis (2004) indicated that despite several criticisms, carrying capacity assessment remains a powerful concept that can be used for planning and management of sustainable tourism; Segrado, Muñoz, and Arroyo (2008) reported that apart from outlining all factors that limit tourism growth, the concept of carrying capacity also indicates compensatory tools to manage tourism flows to a destination; whilst Bonilla and Bonilla (2009) indicated that this concept should be seen as a positive and dynamic prism contemplating the temporal space as a basic value for implementation of sustainable beach management principles.

Understanding that good beaches are worth billions of tourist dollars and degraded beaches are worth little (Clark, 2005), the main objective of this paper is to assess the recreational carrying capacity of Praia de Faro by means of assessing the physicoecological carrying capacity (assuming that every beach has a limiting size of people that it can accommodate) and the sociocultural carrying capacity or the level of interaction between local people and visitors and their responses to crowding. To meet these objectives, 4 major research questions were developed: (1) what is the maximum number of people that should be allowed at Praia de Faro?; (2) has the physical carrying capacity at the beach been exceeded or is it still in the optimum range?; (3) what is the level of interaction between tourists and local communities and among tourists themselves?; and (4) what is the optimum allowed number of people on the beach suggested by these two groups?

\section{Research methods}

\section{Study area}

This research was conducted at Praia de Faro, located in the Ancão Península, the most western system of barrier islands of the Ria Formosa (Fig. 1) in southern Portugal. It is sited in the middle zone of the Ancão Inlet which tends to migrate eastwards (Dias et al. 2004, after Weinholtz 1978). The Ancão spit is approximately $10 \mathrm{~km}$ length but changes temporarily with migration of the Ancão tidal inlet (Ciavola, Dias, Ferreira, Taborda, \& Dias, 1998). Average wind speeds rarely exceed $60 \mathrm{~km} / \mathrm{h}$, blowing dominantly from the southwest, although high-energy events sometimes occur from the northeast and from southeast. Pessanha and Pires (1981) indicated that the typical average values of significant wave height and periods are $0.9 \mathrm{~m}$ and $5.0 \mathrm{~s}$. The beach consists mainly of quartz sands with a smaller fraction of small pebbles and biogenic material.

\section{Physico-ecological carrying capacity}

To assess the physico-ecological carrying capacity, the Carrying Capacity Assessment for Protected Areas framework developed by Cifuentes (1992), and further explained and applied by several other authors (Amador et al., 1996; Ceballos-Lascuráin, 1996; Cifuentes et al., 1999; Munar, 2002; Segrado et al., 2008) was used. This framework attempts to establish the maximum number of visits that an area can have based on the physical, biological and management conditions of the area, considering three main levels: the physical carrying capacity (the maximum number of visitors that can physically fit into a defined area over a particular time), the real carrying capacity (the maximum permissible number of visits to a specific site, once correction factors derived from the particular characteristics of the site have been applied to the PCC) and the effective or permissible carrying capacity (the maximum number of visits that a site can sustain considering the RCC and the management capacity) (Cifuentes et al., 1999). To apply this method, it is important to consider tourist flows, the size of the area, the optimum space available for each tourist to move freely and the visiting time (Cifuentes, 1992).

Based in this model, the physico-ecological carrying capacity was determined by the Equation

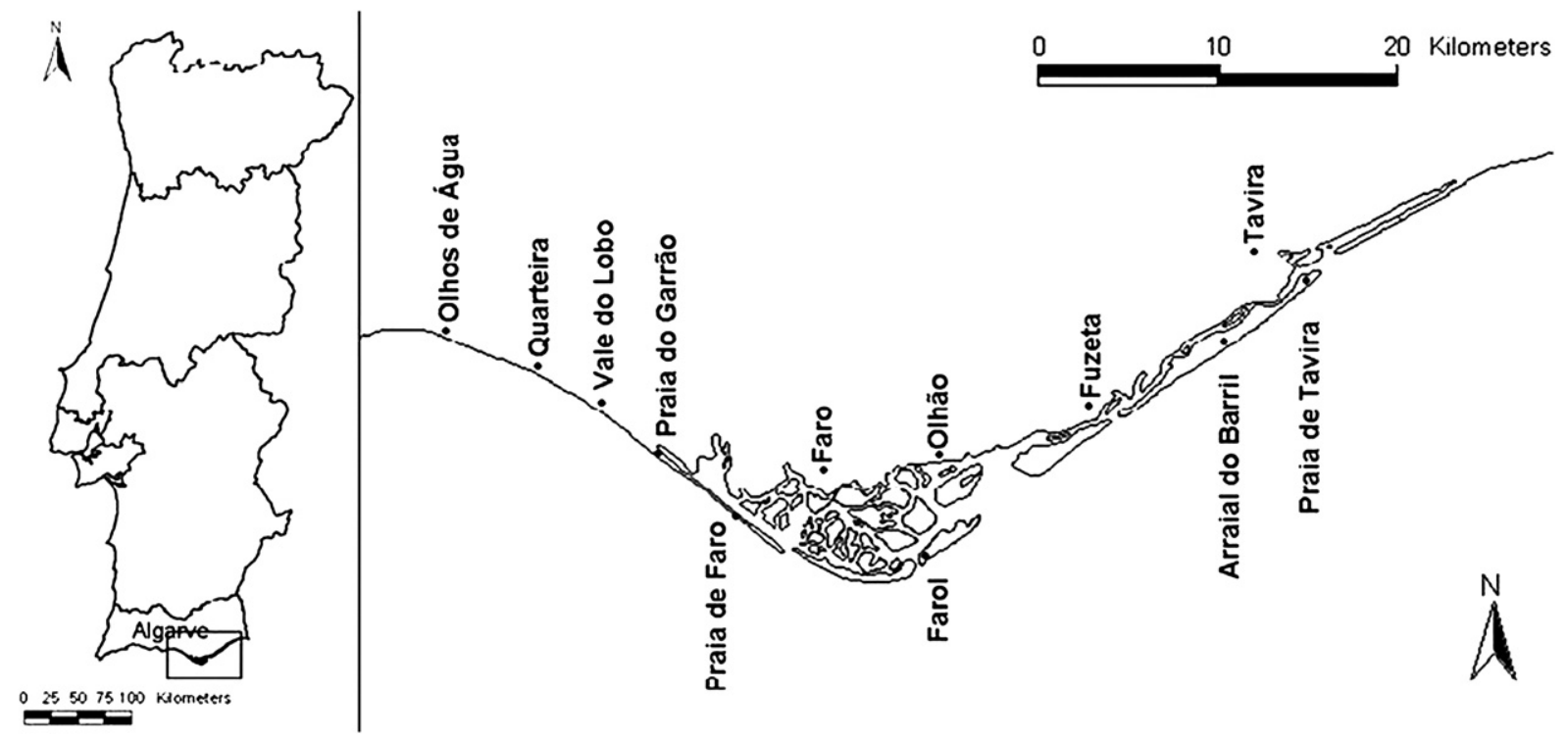

Fig. 1. Location of Praia de Faro, Portugal in the Ria Formosa environment. 


$$
P C C=\frac{A}{A_{u}} \times R_{f}
$$

(Equation (1)) where PCC is the physical carrying capacity, $A$ is the size of the study/visited area, $A_{u}$ is the area available per user and $R_{f}$ is the rotation factor or number of visitors per day. Because studies on the average length of stay at the beach are not available, this last value was adapted from Solé (2007) as an average value for Spanish beaches. The real carrying capacity was determined using Equation

$\mathrm{RCC}=\mathrm{PCC} \times(\mathrm{cf} 1 \times \mathrm{cf} 2 \times \mathrm{cf} 2 \times \ldots \mathrm{cfn})$

(Equation (2)), where RCC is the real carrying capacity, PCC is the physical carrying capacity and $\mathrm{cf}_{1} \ldots \mathrm{cf}_{\mathrm{n}}$ are the correction factors, determined using the Equation

$\mathrm{Cf}_{\mathrm{x}}=1-\frac{\operatorname{Lm}_{\mathrm{x}}}{\mathrm{Tm}_{\mathrm{x}}}$

(Equation (3)), where $\mathrm{Cf}_{\mathrm{x}}$ is the correction factor of variable $\mathrm{x}$, $\operatorname{Lm}_{\mathrm{X}}$ is the limiting magnitude of variable $\mathrm{x}$ and $\mathrm{Tm}_{\mathrm{x}}$ is the total magnitude of variable $\mathrm{x}$. Considering that tourism is dependent upon environmental attributes, six correction factors were considered for this study: rainfall, strong winds, absence of sun, beach erosion and temporary closure, all selected because of their limiting power in the tourism activity, facility of analysis and because of enabling the measurement of the sustainability level of a tourist destination (Cifuentes, 1992; Cifuentes et al., 1999). Data for these parameters was obtained from White Papers and papers published regarding the beach, especially MAOT (2000), Dias et al (2004) and Ciavola et al (1998) and the calculations are presented below:

\section{Rainfall}

Four months are of particular interest in the climatic pattern of the southern tip of Portugal affecting mainly the coastal zone: November, December, January and February with the highest rain patterns with more than $400 \mathrm{~mm}$ on average (MAOT, 2000). The limiting magnitude for this parameter was determined as 120 days/ year, while the total magnitude was the total days of the year (assumed as 365). Therefore, the correction factor for rainfall was determined as 0.6712 or $67.12 \%$.

\section{Strong winds}

This factor was included as it can largely influence the recreational satisfaction of people on the beach by transporting large amounts of sand and or by creating strong waves that can reduce satisfaction of many beach users (except beach surfers that might enjoy these times). In the Algarve region, four months are of particular importance as a result of the eastern winds (June, July, August and September). The limiting magnitude was determined as 122 days/year for Faro Beach with the total magnitude remaining all days of the year (365 days). The corrective factor for this parameter was 0.6658 (66.58\%).

\section{Sunshine}

This can be the most important factor for beach tourism as without sunshine few people go to the beach for recreational activities. Considering MAOT (2000), the Algarve region having $3000 \mathrm{~h}$ of sun per year means that for around $5760 \mathrm{~h}$ there is no sunshine. The limiting magnitude for the absence of sunshine was determined as $5760 \mathrm{~h}$ and as a result, the correction factor of this parameter was determined as 0.3425 or $34.25 \%$.

\section{Temporary closure}

According to the Act 44/2004 of $19^{\text {th }}$ August, the bathing season for Faro Beach is established from $1^{\text {st }}$ June to $30^{\text {th }}$ September. This parameter means that the beach is officially closed for the entire eight months of the year (January, February, March, April, May, October, November and December). The limiting factor for this parameter was determined as 243 days, the total magnitude was 365 days and as a result, the correction factor was calculated as $0.3342(33.42 \%)$.

\section{Beach erosion}

This parameter is of great importance for beach tourism, as it reduces available space for recreation. Considering results provided by Dias et al (2004) and Ciavola et al. (1998), Praia de Faro faces an erosion index of $1.7 \mathrm{~m} /$ year. Using this parameter and ignoring beach nourishment, it may be assumed that Faro Beach loses $3060 \mathrm{~m}^{2} /$ year $(1.7 \mathrm{~m}$ width $\times 1800 \mathrm{~m}$ long). Therefore, the limiting factor was determined as $3060 \mathrm{~m}^{2}$, the total magnitude was the total area of the beach $\left(90,000 \mathrm{~m}^{2}\right)$ and the corrective factor was calculated as $0.966(96,6 \%)$.

The effective carrying capacity is a result of the combination of the real carrying capacity with the management capacity of the area, as described by the Equation

$\mathrm{ECC}=\mathrm{RCC} \times \mathrm{Mc}$

(Equation (4)), where ECC is the effective carrying capacity, RCC is the real carrying capacity and Mc is the management capacity. This last parameter was determined using infrastructure and equipments available, assessed by means of beach users' perception and evaluation during the survey period with results showing an overall capacity of $83.8 \%$.

\section{Socio-cultural carrying capacity}

Several methods and approaches have been extensively used to assess carrying capacity in coastal areas (Pereira da Silva, 2002a, b; UNEP/PAP, 1997). Unfortunately, none of these methods have been utilised in the study area singular, as no previous studies have ever been conducted. To develop this study a combination of literature analysis, field surveys, structured interviews, stakeholders' mapping tool and scenario analysis were employed.

Data was obtained from surveys from questionnaires administered at the beach from $15^{\text {th }}$ July to $15^{\text {th }}$ August. During these days and following a random procedure for days of the week and periods of time, visitors to the beach were approached and asked to fill in a questionnaire in accordance to standard procedures that could cover $10 \%$ of the total number of tourists in the beach as applied by Needham et al (2008). Questionnaires included a wide range of topics, from prior visitation, activities involved, the level of satisfaction, encounters, crowding, norms, values and potential support to management strategies in a combination of close-ended questions and five-point Likert-scaled questions. All questionnaires were incorporated in a Microsoft Excel datasheet for data collapsing and integration and, where necessary, analysis were conducted using the Statistical Package for Social Sciences (SPSS 17.0) looking for percentages, cross-tabulations and multivariate statistical techniques (chi-square, $t$-tests conjoint modelling).

Additionally, beach users were asked to identify their perceived sense of crowding and reported encounters in accordance to Manning (1999) and Manning, Wang, Valliere, Lawson, and Newman (2002) based on 15 different levels $(0,5,10,20,35,50$, $75,100,200,350,500,750,1000,1500$ and $2000+$ people) as suggested by Needham et al (2008). Because the only application of the close-ended format to assess the maximum number of people may be unrealistic and may not accurately ascertain these values, especially in places with high use levels (Manning, 1999, 2007; Manning et al., 2002; Needham et al., 2008), respondents were additionally asked to rate from a set of photographs (Fig. 2) one that was much similar to the reality, with encounters and capacities 

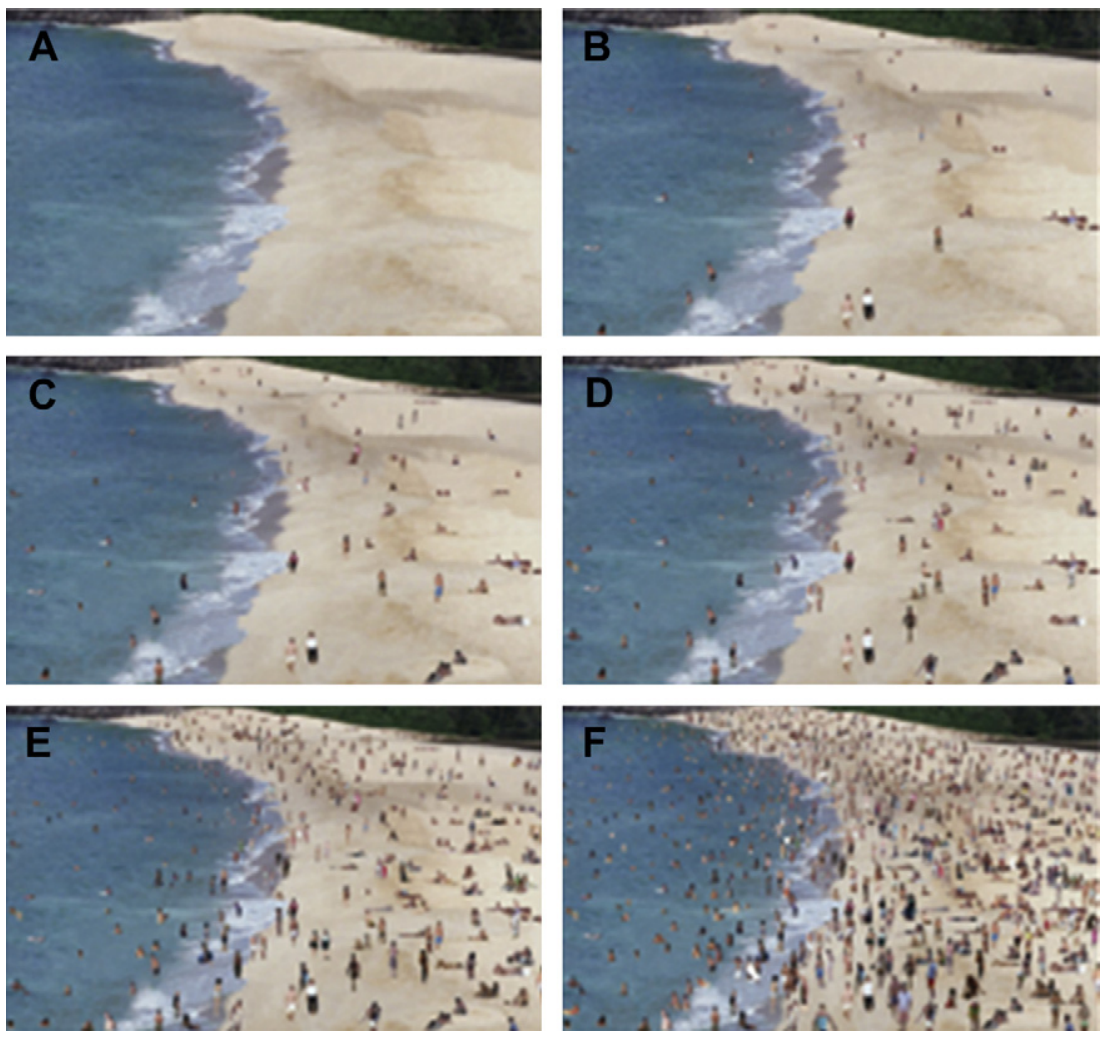

Fig. 2. Photographs used for measuring encounters and use level norms (retrieved and adapted from Needham et al., 2008).

being estimated by first dividing the beach total area by the corresponding unit standard in the photograph and then multiplying by respondents evaluation at the site in accordance with Needham et al (2008).

\section{Results and discussion}

\section{Physico-ecological carrying capacity}

Results of the field show that Praia de Faro covers $90,000 \mathrm{~m}^{2}$ (1800 $\mathrm{m}$ long and $50 \mathrm{~m}$ wide), with tourist flows concentrated in the summer season. Considering the area of the beach, an optimum area available per user $\left(5 \mathrm{~m}^{2}\right.$ for scenario 1 and $10 \mathrm{~m}^{2}$ for scenario 2) and a rotation factor of 4 (Solé, 2007), the physical carrying capacity was estimated at 72,000 visits/day (scenario 1 ) and 36,000 visits/day (scenario 2), meaning that the maximum number of people at the beach should never exceed this range and demonstrates the importance of the rotation factor as a management indicator for beach tourism management strategies development. These numbers are only theoretical and incorporating the correction factors is the way used to correct PCC to obtain RCC. Considering the correction factors and after application of Equation (2), the real carrying capacity was estimated at 3558 and 1779 visitors/ day (scenario 1 and 2 respectively), meaning that although a certain amount of tourists can fit in at the beach, reality shows a different situation, because as the number of beach tourists increases, visitors feel that the destination is losing quality, the capacity to recover the beach is costly and the environmental quality smoothly decreases its natural properties (Aranguren et al., 2008). Although the carrying capacity has significantly decreased, an important aspect should be included: the management capacity of the beach. According to Cifuentes (1992), to measure management capacity it is necessary to address several variables such as the juridical background, policies and regulations, equipment, personnel, funding, infrastructure and facilities and the management capacity would be defined as the best status or conditions that beach administrators should keep in order to develop their activities and meet proposed objectives (Cifuentes, 1992:22; Cifuentes et al., 1999:23).

The effective carrying capacity (Equation (3)) was calculated as 2982 and 1491 visitors/day (scenario 1 and 2). As suggested by Cifuentes (1992), Cifuentes et al., (1999), Arangunen, Moncada, Naveda, Rivas, and Lugo (2008) and Segrado et al. (2008), these results should not be accepted easily, as interpretation can assume several forms. The 1491-2982 visits/day indicates the number of people that should be allowed in the beach with existing conditions and management capacity, but, during one season there are days with much more people and days without people in the beach. Generally, tourism as a vehicle of culture, prosperity and peace (Patil \& Patil, 2008) must conserve without damaging, protect without plundering and create without destroying. Especially in coastal areas, this statement achieves greater significance if we understand beaches as eco-social landscapes (Baldwin, 2007) in which use patterns, perceptions and behavioural attitudes are completely dependent on the users or tourists. As a result of these patterns, there is a need to preserve and protect these fragile natural sites but at the same time enabling full enjoyment of people.

By determining the usage level of an area without exceeding certain levels, the physical carrying capacity has been extensively viewed as a panacea for beach management and as a tool to reduce impacts from tourism (Patil \& Patil, 2008). However, McCool and Lime (2001) do not share this same view basing their arguments on the subjectivity when identifying the desired level of each indicator and the difficulties of establishing the relationship between number of visitors and each indicator. Another point that generates controversy around physical carrying capacity is that it 
does not consider the level of interaction between tourists themselves and between tourists and local communities.

\section{Socio-cultural carrying capacity}

Two-hundred and seventy-five valid questionnaires were used, being 128 for local people ( 75 females and 53 males) and 147 for tourists ( 72 females and 71 males). Interviewed beach users' were at the beach mostly for sunbathing (26\%), swimming (23\%) and beach walking (20\%). Their overall level of satisfaction was very high with $77 \%$ of them being satisfied, $15 \%$ dissatisfied and the remaining $9 \%$ not being able to state. Although most respondents were satisfied with the overall visit, this cannot be taken as an indicator of the quality of experiences and conditions of the beach as high levels of overall satisfaction are common in recreation but do not demonstrate the reality and are quite useless for management purposes (Manning, 1999; Needham et al., 2008).

As a mean to accommodate this parameter, the multiple satisfaction approach (Hendee, 1974) was used, where beach users' were asked to rate the level of importance and satisfaction of existing and hypothetical conditions via a 5 -points scale $(1=$ most negative value and $5=$ most positive value) with results represented in Fig. 3.

As shown in Fig. 3, the bulk of respondents considered most characteristics and conditions important for their enjoyment and satisfactions, although picnic tables and beach benches were rated as not important. This can be explained by the fact that most beach users were at the beach mainly for swimming and beach walking. When related to satisfaction most respondents were satisfied by the facilities and conditions offered although parking facilities (49\%), picnic tables (63\%), beach benches (49\%) and the opportunity to escape crowds (63\%) did not meet users' requirements. Because carrying capacity is related to management, there was a need of assessing the real extent of the problem and address major lines of action. For this purpose, the importance-performance (IP) matrix was applied based on the fundament that that respondents can be satisfied with a particular characteristic of the setting or experience, but feel that it is not important that the characteristic is actually provided and therefore it is important to understand relationships between both importance and satisfaction (Needham et al., 2008:27).

\section{a}

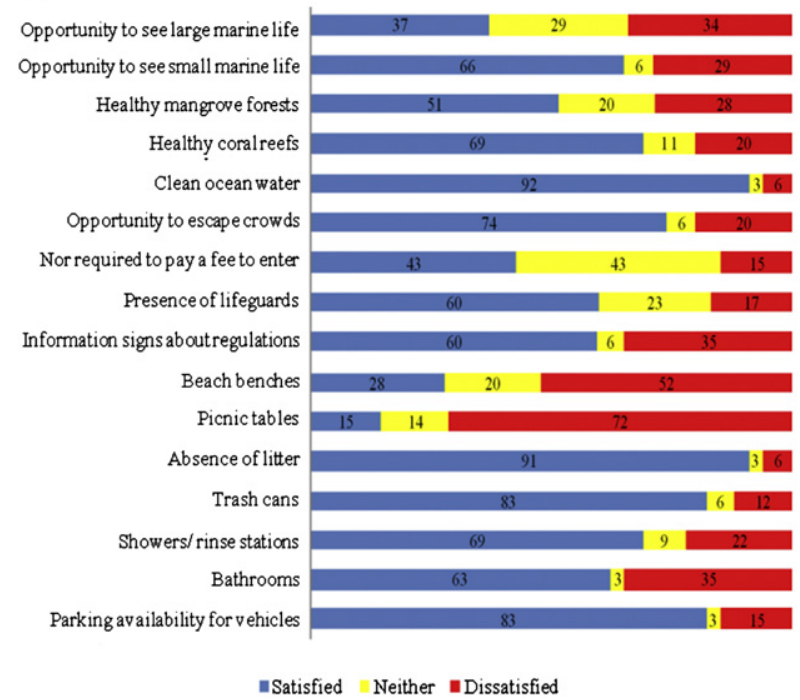

Its application required conversion of the original 5-points Likert-scale from 1 to 5 into another set ranging from -2 to 2 in accordance with Manning (1999) and Needham et al., 2008 and respective values plotted with importance in the $y$-axis and satisfaction in the $x$-axis in order to be represented in 4 quadrats ( $\mathrm{A}=$ 'concentrate here'; $\mathrm{B}=$ 'keep up the good work'; $\mathrm{C}=$ 'low priority'; $\mathrm{D}=$ 'possible overkill') as suggested by Hollenhorst, Olson, and Fortney (1992); Siegenthaler (1994); Slack (1994); Chu and Choi (2000) and Needham et al (2008). As presented by Fig. 3, respondents at Faro Beach rated important and were satisfied with most of the characteristics suggesting a 'keep up the good work' line of action, related to car parking facilities (importance $=0.93$; satisfaction $=0.02)$, trash cans $(1.24 ; 0.40)$, showers and rinse station $(0.63 ; 0.29)$, lifeguards $(0.54 ; 0.40)$, information about regulations $(0.28 ; 0.56)$, clean ocean water $(1.26 ; 1.06)$, absence of litter (1.17; $1.17)$ and no requirement to pay entrance fees $(0.39 ; 1.20)$.

Though, they send a 'concentrate here' message to managers, especially when related to bathrooms $(0.36 ;-0.50)$ and the opportunity to escape crowds $(0.73 ;-0.54)$ that were rated important, but respondents were not satisfied by the existing conditions in the beach. The fact that the opportunity to escape crowds was rated important but beach users did not feel satisfied, can be the first indicator of peoples' capacity to accept other users. Picnic tables $(-0.94 ;-0.62)$, beach benches $(-0.37 ;-0.14)$ and the opportunity to see large marine life $(-0.04 ;-1.31)$ were considered by the respondents as low priority issues, the last contrasting with the opportunity to see small marine life $(0.41 ;-0.05)$ that was rated a 'concentrating' issue. Although parking availability was considered satisfactory, special attention should be addressed to it, as the satisfaction rate was very low and can at any instance drop to a concentrating point.

As a result of the application of the perceived sense of crowding (Fig. 4) approach, for 66 beach users (43 locals and 13 tourists) the number of people did not matter, 51 (43 locals and 8 tourists) could not specify a number and the remaining 167 (42 locals and 125 tourists) were able to specify a number. From the specified responses, the mean acceptable value was determined as 640 other users (from local people) and 740 other users (from tourists).

Following this method, photograph $\mathrm{E}$ was the most rated with $84 \%$, meaning that beach users had encountered 282 other users during their visit. Because photographs used do not cover the entire

\section{b}

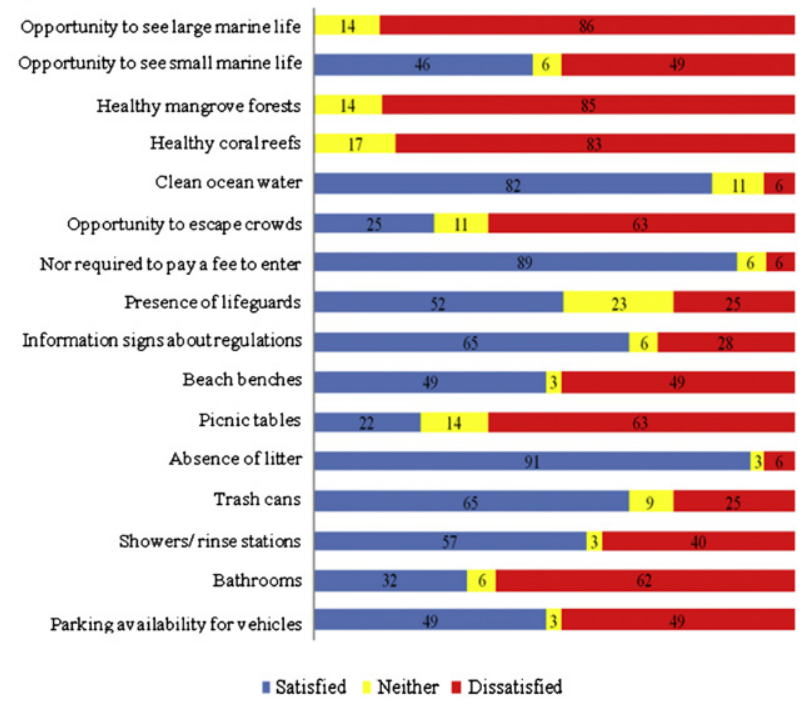

Fig. 3. Relative importance (a) and satisfaction (b) with beach conditions and facilities at Faro Beach. Numbers represent percentages of respondents in each category. 


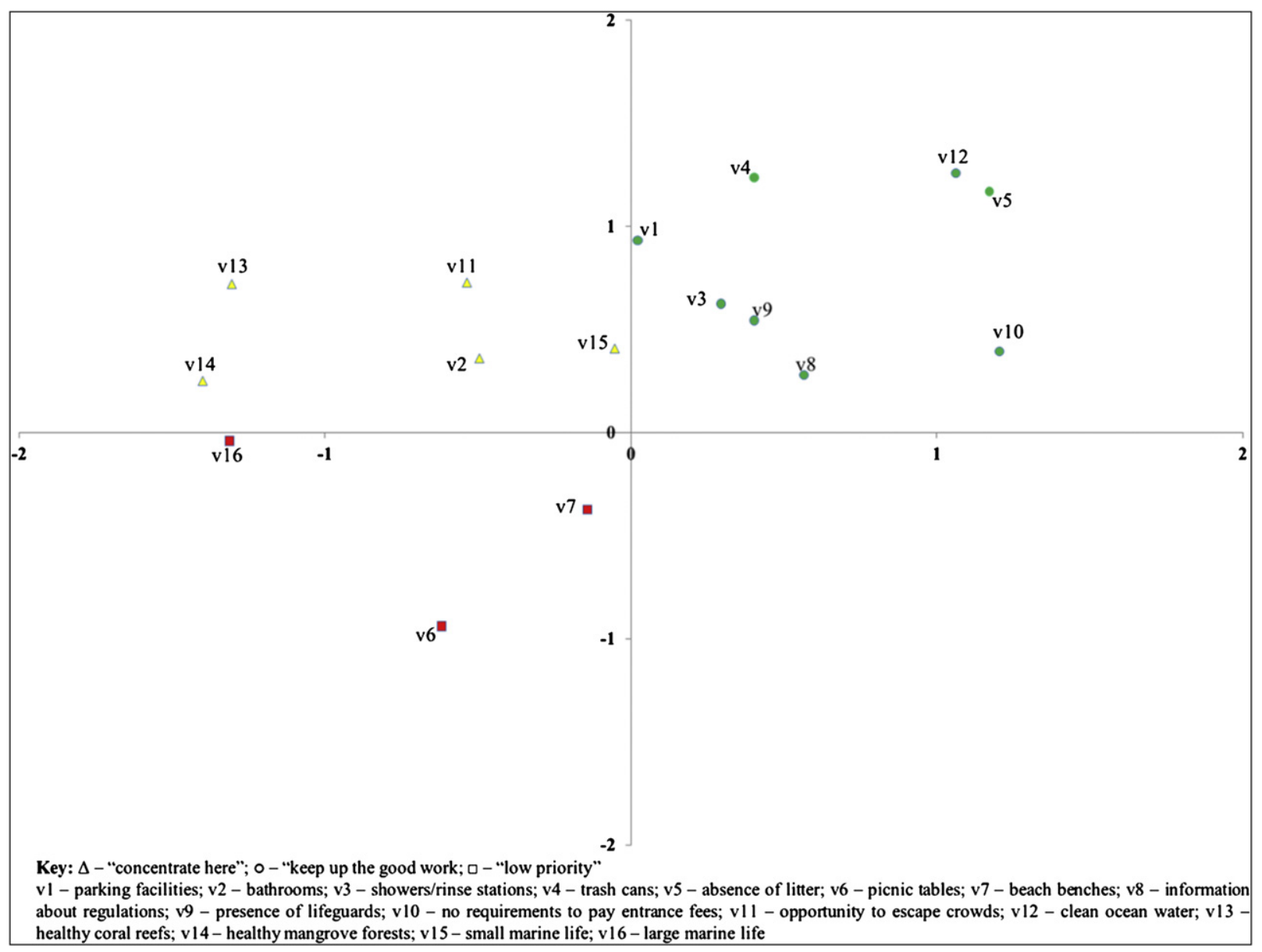

Fig. 4. Importance-performance matrix at Praia de Faro, Portugal.

beach and assuming that beach users cannot see the entire beach, this value was extrapolated to the entire environment and the near most number of other people encountered at the beach was 307 . There was a statistical difference in the application of these two methods $(t=2.603, \alpha<0.05)$. As knowing reported encounters may not reveal maximum acceptable use levels (Needham et al., 2008:32), beach users were asked to rate the acceptable density of people represented in each photograph if it was to occur at the beach, with results coded in a 5-point scale ( -2 to 2 ) and average values plotted as social norm curves (Manning et al., 2002) indicate at which conditions use levels reach unacceptable levels (Fig. 5).

As described in Fig. 5, the impact acceptability curve (social norm curve) for encounters with other people shows that on average local people rated acceptable photographs B, C, D and E, containing 50,100, 200 and 300 beach users per $457 \times 182 \mathrm{~m}$ while tourists rated acceptable photographs C, D and E. When extrapolated to the entire beach, optimum acceptable use levels were established from 76 to 305 other users (for local people) and from 76 to 608 other users (for tourists) with high levels of crystallization ( 0.33 for local people and 0.23 for tourists in a range of 2 points). As shown, for beach users at Praia de Faro an empty beach (photograph A) would not be a pristine condition for their enjoyment and experience, but for local communities an overcrowded beach (photograph F) would have an otherwise effect.

Two different datasets have been identified in this paper and the question is which parameter should be the best option to ensure adequate tourism and appropriate coastal management. As presented by Williams and Micallef (2009:31, 445), beach management is a catholic spectrum of potential conflict... reflecting the taking of decisions to undertake or not undertake actions that reflect governing policy objectives and the socio-economic and environmental capabilities of beach areas. While the results of the physicoecological carrying capacity can be much easily accepted by local governments, because large numbers of people represent large amounts of revenue, the socio-cultural carrying capacity might represent the real willing of the people who use the beach as few

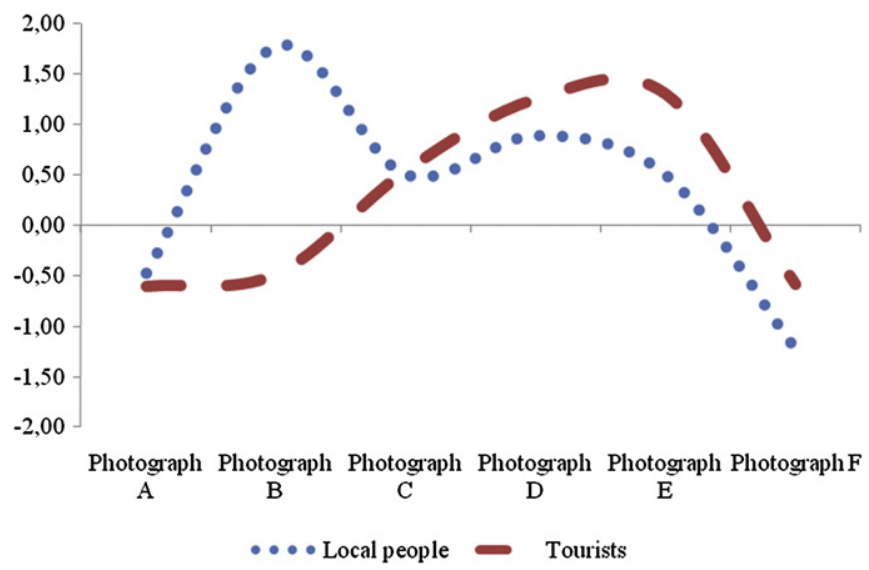

Fig. 5. Impact acceptability curves for encounters between tourists and local people at Praia de Faro. Photographs used were as in Fig. 2. 
people represent much space for leisure activities. So, what is the right way to manage a beach/coast, or is there a right way? (Williams \& Micallef, 2009:31, 445). Considering that local participation is a powerful towards development and that beach users are the ultimate agents in tourism and coastal management, it seems that the adoption of the socio-cultural carrying capacity results would be the most reasonable way to ensure visitor's enjoyment and safeguard the long-term survival of coastal environments, in this case Praia de Faro.

\section{Conclusions}

Coastal resources management is a great challenge for both tourism planners and coastal managers and the issue of ascertaining the optimum usage levels of resources is a great task to be performed. As tourism flows are ever growing, the probability of increasing the rate of environmental hazards is also increasing and sustainable approaches need to be implemented. Among several approaches, carrying capacity assessment remains one of the most useful and applied techniques. At Praia de Faro, the physical carrying capacity is reported as $1491-2982$, which contradicts the values of 72,000 (scenario 1) and 36,000 (scenario 2) reported on page 6 . Though, these values should not be seen as the number of people that the beach can accommodate as a permanent fix of these huge numbers of visits at one time would be a disaster. Alternatively, the socio-cultural carrying capacity was estimated at 305 and 608 beach users. However, defining the optimum number of beach users a beach can support is not the end and there is a need of applying other frameworks that based on the upper limits of acceptance can help in the process of identifying the load or the level of impact that the beach will sustain and codes of conduct that beach users should follow.

\section{Acknowledgements}

This paper is part of a dissertation for a masters' degree in the European Joint Master in Water and Coastal Management, Erasmus Mundus at the University of Algarve, Portugal. The European Community played a major role in the program by sponsoring the first author a scholarship to undertake the program. Two anonymous reviewers provided useful insights towards the final quality of the paper.

\section{References}

Amador, E., Bliemsrieder, M., Cayot, L., Cifuentes, M., Cruz, E., Cruz, F., et al. (1996) Plan de manejo del Parque Nacional Galápagos. Servicio Parque Nacional Galápagos. Instituto Forestal y de Áreas Naturales y Vida Silvestre, Puerto Ayora, Galápagos.

Arangunen, J., Moncada, J. A., Naveda, J., Rivas, D., \& Lugo, C. (2008). Evaluación de la capacidad de carga turística en la playa Conomita, Municipio Guanta, Estado Anzoátegui. Revista de Investigación, 64, 31-36.

Baldwin, J. (2007). Understanding tourist beaches as eco-social landscapes: Seeking sustainability through integration of human and non-human wealth production. Études Caribéennes, 7/2007. Les risques naturels majeurs dans la Caraïbe. Available at: http://etudescaribeennes.revues.org/document332.html.

Bonilla, J. M. L., \& Bonilla, L. M. L. (2009). La capacidad de carga turística: revisión crítica de un instrumento de medida de sostenibilidad. El Periplo Sustentable. $15,123-150$.

Ceballos-Lascuráin, H. (1996). Tourism, ecotourism, and protected areas: the state of nature-based tourism around the world and guidelines for its development. IV World Congress on National Parks and Protected Areas. IUCN, Protected Areas Programme.

Chu, R. K. S., \& Choi, T. (2000). An importance-performance analysis of hotel selection factors in the Hong-Kong hotel industry: a comparison of business and leisure travelers. Tourism Management, 21, 363-377.

Ciavola, P., Dias, N., Ferreira, O., Taborda, R., \& Dias, J. M. A. (1998). Fluorescent sands for measurements of longshore transport rates: a case study from Praia de Faro in southern Portugal. Geo-Marine Letters, 18, 49-57.
Cifuentes, M. A. (1992). Determinación de capacidad de carga turística en áreas protegidas. Costa Rica: Biblioteca Orton IICA/CATIE.

Cifuentes, M. A., Mesquita, C. A. B., Méndez, J., Morales, M. E., Aguilar, N., Cancino, D., et al. (1999). Capacidad de carga turística de las áreas de Uso Público del Monumento Nacional Guayabo, Costa Rica. Costa Rica: WWF CentroAmerica.

Clark, J. R. (2005). Coastal zone management handbook. Florida: CRC Press, Inc.

Dharmaratne, G. S., \& Braithwaite, A. E. (1998). Economic valuation of the coastline for tourism in Barbados. Journal of Travel Research, 37(2), 138-144.

Dias J.M.A, Ferreira O, Moura D (2004). O sistema de ilhas-barreira da Ria Formosa, In. 3rd Interdisciplinary Symposium on Wetlands. Castro Marim, Portugal

Hendee, J. C. (1974). A multiple-satisfaction approach to game management. Wildlife Society Bulletin, 2, 104-113.

Hollenhorst, S., Olson, D., \& Fortney, R. (1992). Use of importance-performance analysis to evaluate State Park Cabins: the case of the West Virginia State Park system. Journal of Park and Recreation Administration, 10(1), 1-11.

Houston, J. R. (2002). The economic value of beaches - A 2002 Update. Shore and Beach, Vol. 70(1), 9-12.

Kanji, F. (2006). A global perspective on the challenges of coastal tourism. Coastal Development Centre.

Manning, R. (1998). "To provide for the enjoyment": recreation management in the National Parks. George Wright Forum, 15, 6-20.

Manning, R. E. (1999). Studies in outdoor recreation: Search and research for satisfaction ( $2^{\text {nd }}$ ed.). Corvallis: Oregon State University Press.

Manning, R., Wang, B., Valliere, W., Lawson, S., \& Newman, P. (2002). Research to estimate and manage carrying capacity of a tourist attraction: a study of Alcatraz Island Journal of Sustainable Tourism, 10(5), 388-403.

MAOT. (2000). Plano de bacia hidrográfica das ribeiras do Algarve: análise e diagnóstico da situação de referência, Vol. 3. Lisboa: Ministério do Ambiente e do Ordenamento do Território.

McCool, S. F., \& Lime, D. W. (2001). Tourism carrying capacity: tempting fantasy or useful reality? Journal of Sustainable Tourism, 9(5), 372-388.

Mexa, A., \& Coccossis, H. (2004). Tourism carrying capacity: a theoretical overview. In $\mathrm{H}$. Coccossis, \& A. Mexa (Eds.), The challenge of tourism carrying capacity assessment: Theory and practice. England: Ashgate.

Munar, F. X. R. (2002). Análisis de capacidad de carga en los espacios litorales, calas e playas, situados en áreas naturales de especial interés de la Isla de Menorca. Spain: Universidad de Almería.

Needham, M. D., Tynon, J. F., Ceurvorst, R. L., Collins, R. L., Connor, W. M., \& Culnane, M. J. W. (2008). Recreation carrying capacity and management at Kailua beach Park on Oahu, Hawaii. Hawaii Coral Reef Initiative research program. Oregon State University.

Papageorgiou, K., \& Brotherton, I. (1999). A management planning framework based on ecological, perceptual and economic carrying capacity: the case study of Vikos-Aoos National Park, Greece. Journal of Environmental Management, 56, 271-284.

Patil D.Y, Patil L.S (2008). Environmental carrying capacity and tourism development in Maharashtra. In. Conference on Tourism in India - Challenges Ahead, May 15-17. IIMK

Pereira da Silva, C. (2002a). Beach carrying capacity assessment: how important is it. Journal of Coastal Research, 36, 190-197.

Pereira da Silva C (2002b). Integração de estudos de percepção da paisagem e imagens digitais na definição da capacidade de carga de praias: o troço litoral $S$. Torpes - Ilha do Pessegueiro. PhD Thesis. Universidade Nova de Lisboa, Portugal. p. 361

Piquera, V.Y (2005). Gestión del uso público según el sistema de calidad turístico español. VIII Jornadas Españolas de Costas e Puertos, 17 e 18 Mayo. Sitges

Segrado, R., Muñoz, A. P., \& Arroyo, L. (2008). Medición de la capacidad de carga turística de Cozumel. El Periplo Sustentable, 13, 33-61.

Shore Protection Manual. (1984) Shore Protection Manual, Vol. 3. Washington DC. USA: US Government Printer.

Siegenthaler, K. L. (1994). Importance-performance analysis: application to senior programs evaluation. Journal of Park and Recreation Administration, 12(3), 57-70.

Slack, N. (1994). The importance-performance matrix as a determinant of improvement priority. International Journal of Operations $\mathcal{E}$ Production Management, 14(5), 59-75.

Solé, E.A. (2007). A system of integral quality indicators as a tool for beach management. Unpublished $\mathrm{PhD}$ dissertation. University of Catalunya. Spain

UNEP/PAP. (1997). Guidelines for carrying capacity assessment for tourism in Mediterranean coastal areas. Turkey: Priority Actions Programme Regional Activity Centre. Split.

Vaz, B., Williams, A. T., Pereira da Silva, C., \& Phillips, M. (2009). The importance of users' perception for beach management. Journal of Coastal Research, $56,1164-1168$.

Weinholtz, M. de B. (1978). Contribuição para o estudo da evolução das flechas de areia na costa sotavento do Algarve (Ria de Faro). Relatório da Direcção-Geral de Portos.

Williams, A. T., \& Micallef, A. (2009). Beach management: Principles and practice. Earthscan.

WTO. (1981). Technical handbook on the collection and presentation of domestic and international tourism statistics. World Tourism Organization: Madrid. 